\title{
Compromise sought over germplasm access
}

Washington. A new set of rules covering the potential use by agricultural biotechnology companies of germplasm stored in international agricultural research centres (IARCs) across the world has been proposed by the director general of the International Plant Genetic Resources Institute (IPGRI).

The proposed rules would require private-sector recipients of germplasm held by the gene banks to agree not to seek intellectual property protection on such material unless it was substantially modified through breeding programmes.

At the same time, companies wishing to market agricultural products derived from the germplasm would be required to negotiate royalty agreements with the countries from which it originally came.

The proposals were presented to the annual meeting of the Consultative Group on International Agricultural Research (CGIAR) at the World Bank in Washington last week. CGIAR is a confederation of 16 IARCs spread across the globe and widely recognized as having brought green revolution agriculture to the developing world.

Geoffrey Hawtin, director general of IPGRI, which is based in Rome, told the meeting that a new environmental ethic, based on the concept of the ownership of genetic resources and promoted by the United Nations (UN) Convention on Biological Diversity agreed in Rio de Janeiro in 1992, threatened to deter future increases in world food production by restricting the free flow of germplasm.

Supporters of the ownership concept argue that it will provide financial incentives for the conservation of biodiversity. But ironically, said Hawtin, it could wreak havoc with CGIAR breeding programmes, as these can require parental lines from more than half a dozen countries to produce new high-yielding varieties of rice, wheat or maize.

The CGIAR routinely releases these new varieties free of charge to national breeding programmes. Hawtin's proposal would require standardized material transfer agreements to accompany every shipment of germplasm from source countries to CGIAR gene banks.

Under the new proposals, "if you commercialize something, everyone, both North and South, will share the benefits", says Hawtin. "It's never going to be perfect, but frankly the alternative is that no materials move [between breeding programmes]."

At last week's meeting, the CGIAR also signed a memorandum of understanding with the UN Food and Agriculture Organization (FAO) placing nearly 500,000 genetic accessions within its gene banks "in trust" under the UN.

The move to name the FAO as the trustee of CGIAR germplasm is intended to fore-

\section{IMAGE UNAVAILABLE FOR COPYRIGHT REASONS}

\section{A 'gene fund' could help pay for gene conservation programmes}

stall accusations by source countries that either the CGIAR or the World Bank now intends to lay claim to these valuable genetic resources. Under the terms of the new memorandum, the CGIAR promises not to seek intellectual property rights on any germplasm held in its collections.

Although IPGRI is known for promoting ex situ conservation of germplasm around the globe, there is growing pressure on the CGIAR to devise new incentives for the in situ preservation of local or traditional crops, known as landraces.

M. S. Swaminathan, director of the Centre for Research on Sustainable Agriculture

and Rural Development in Madras, India, submitted a report containing a proposal for a system-wide intellectual property policy. He suggested that one way of doing this would be to introduce the concept of "farmers' rights" to protect the intellectual property in informal agricultural innovations.

Swaminathan told the CGIAR meeting that farmers' rights protection - like patents or plant-variety protection - would allow farm-based innovators to profit from their inventiveness and their efforts to conserve landraces in situ.

Brushing aside criticism of the practical obstacles facing such a scheme, Swaminathan pointed to the current debate in India on draft legislation to create a system of "genetic identity centres" able to establish the ownership of informal genetic innovations with local crops.

If such landraces were eventually bred into hybrid commercial varieties, then the fact that they had been registered with the Indian Ministry of Agriculture would create the basis for claiming royalties on their use.

In order to simplify the thousands of competing claims that would result from such a system of farmers' rights, Swaminathan and others have proposed the creation of a "community gene fund", financed through a five per cent royalty or tax on the gross sales of commercial hybrid seeds derived from registered landraces.

Such a gene fund, he argued, could pay for hundreds of small-scale in situ conservation projects throughout India, helping individual farmers to work towards the conservation of landraces.

Daniel Putterman

\section{Road cuts urged to combat warming}

London. Britain's Royal Commission on Environmental Pollution last week recommended halving the current UK road-building programme in order to achieve the sharp reduction in carbon dioxide emissions from cars and lorries needed to help stem the rising concentration of greenhouse gases in the atmosphere.

The commission also proposed shifting road policy away from the private car and towards public transport. And it recommended that fuel duty should be increased by another 4 per cent on top of the 5 per cent year-by-year increase in real terms to which the UK government is already committed. That would lead to a doubling of the price of fuel by 2005 .

The report has taken two and a half years to complete and contains 110 recommendations and 17 proposed targets to meet the eight objectives identified by the commission. The objectives include increasing the proportion of trips made by environmentally less damaging modes, achieving standards of air quality that will not damage human health, reducing noise nuisance from transport and reducing carbon dioxide emissions from transport.

Sir John Houghton, the chairman of the commission, is also co-chairman of Working Group 1 of the Intergovernmental Panel of Climate Change (IPCC). The panel has consistently argued that global carbon dioxide emissions must be reduced well below 1990 levels if the concentration of greenhouse gases in the atmosphere is to stabilize at levels that prevent 'dangerous' climate change.

Figures issued by the UK Department of the Environment in late 1992 show that, although total UK carbon dioxide emissions fell by 10 per cent between 1970 and 1990 , emissions from transport increased by 65 per cent. They also show that transport accounts for all the projected increase of 39 million tonnes of carbon a year between 1970 and 2020, with two-thirds coming from private cars.
Maggie Verrall 